\title{
RESEARCH ON THE VARIABILITY OF YIELD COMPONENTS IN SOME GRAPEVINE VARIETIES FOR RED WINES
}

\author{
Giancarla Velicevici ${ }^{1}$, Emilian Madoşă $^{1 *}$, Adriana Ciulca ${ }^{1}$, Sorin Ciulca ${ }^{1}$, Mihaela Mălăescu ${ }^{1}$, \\ Eleonora Nistor ${ }^{1}$, Carmen Beinsan ${ }^{1}$ \\ ${ }^{1}$ Banat's University of Agricultural Sciences and Veterinary Medicine „King Michael I from Romania” Timişoara, \\ Calea Aradului 119, Timişoara, Romania
}

\begin{abstract}
Research was conducted during two growing seasons (2017-2018) in Miniş-Măderat vineyard. The study aimed to evaluate the variability of several red wine grape varieties in order to highlight their main qualitative and quantitative parameters. In the research were involved the morphological parameters: the number of bunches on the vine, the bunch weight, the number of berries in the bunch and the grape yield on the vine. The highest bunches number /vine registered Merlot variety (30.24), while Burgund variety recorded the lowest values (17.76). Burgund variety recorded the highest bunch average weight $(119.57 \mathrm{~g})$ while Pinot Noir recorded the lowest value $(87.18 \mathrm{~g})$. Merlot variety recorded the highest number of berries/bunch,(111.36) and the lower value was recorded by the Pinot Noir (82.36).The Merlot variety achieved a significantly higher production than the other varieties during both growing seasons $(3600.87 \mathrm{~g})$. The conditions of 2018 growing season had a very significant positive influence on the grape yield/vine.
\end{abstract}

Keywords: grapevine, quantitative parameters, variability.

\section{INTRODUCTION}

Grapevine (Vitis vinifera) is one of the most economically important fruit crops and a productive drought stress-adapted plant (Zörb et al., 2014). At first, the cultivation of vines and the production of wine were an identity element of European civilization, then followed the "universalization" of wine, so that today wine is a criterion for assessing the quality of life, almost everywhere in the world. (Stoica, 2016). Production of quality grapes suitable for wine-making depends on numerous factors (Gerendás et al., 2013). Productivity is a complex trait, conditioned by the hereditary basis of the genotype and to a certain extent by the pedo-climatic conditions or the applied agrotechnics. Genetic dowry is crucial in achieving the characteristics of fruiting, and agrotechnics and pedoclimatic conditions regulate the fruiting load and partially the size and number of fruiting (Madosa,2004). The size of the bunches is a variety character, polygenically determined, based on phenotypic realization, additivity effects. However, environmental conditions and applied agrotechnics can influence it. In conditions of drought and a large number of bunches on the stump, the size of the bunches will be reduced. As the size of the bunch decreases, so does the size of the 


\section{Current Trends in Natural Sciences}

Vol. 10, Issue 19, pp. 307-312, 2021

https://doi.org/10.47068/ctns.2021.v10i19.039

Current Trends in Natural Sciences (on-line)

ISSN: 2284-953X

Current Trends in Natural Sciences (CD-Rom)

ISSN: 2284-9521

ISSN-L: 2284-9521

ISSN-L: 2284-9521

grains. The control of this feature can also be achieved through special care work. (Kuhn et al., 2014).

The vine was influenced by climatic factors in all stages of development, but extreme temperatures are those that can cause irreversible damage (Dobrei et.al., 2014). During ripening, high temperatures are beneficial for accumulating sugars, flavors, anthocyanins, acidity, while low temperatures in early bud-break time can cause great damage to viticulture or in variationharvest season when the yield and quality of grapes and wine are influenced (Jardao et.al., 2015; Nistor et.al, 2017). Each grape variety has a distinct characteristic and a series of flavors and tastes customized by the growing area and the applied technology. Each factor that influences the aroma and quality of the grapes is reflected in the wine glass (Jukes, 2015).Different geography and climate lead to wines with different tastes from one region to another, even if they are obtained from the same grape variety. The differences can appear even in the same wine region, depending on the variations of the relief, the composition of the soil and the microclimate, here intervening the term "terroir." (Old Marnie, 2016)

\section{MATERIALS AND METHODS}

The biological material were represented by Four grape varieties for red wines: Pinot Noir, Burgund, Merlot, Cabernet Sauvignon. The study was carried out during two years (2017-2018) on the Pâncota locality area, Arad County, in the pedo-climatic conditions from the Miniş-Măderat vineyard. The precipitation and air temperature were recorded during the research, by using data from the Meteobot@Pro weather station installed in the vineyard. There were also dry periods such as July 2017, or September 2018. In both growing seasons, the lowest temperatures were recorded in January and the highest in August. The experiment was organised in randomized block design with three replications. The researches and observations were carried out following the application of the technology specific to the conventional grapevine growing.

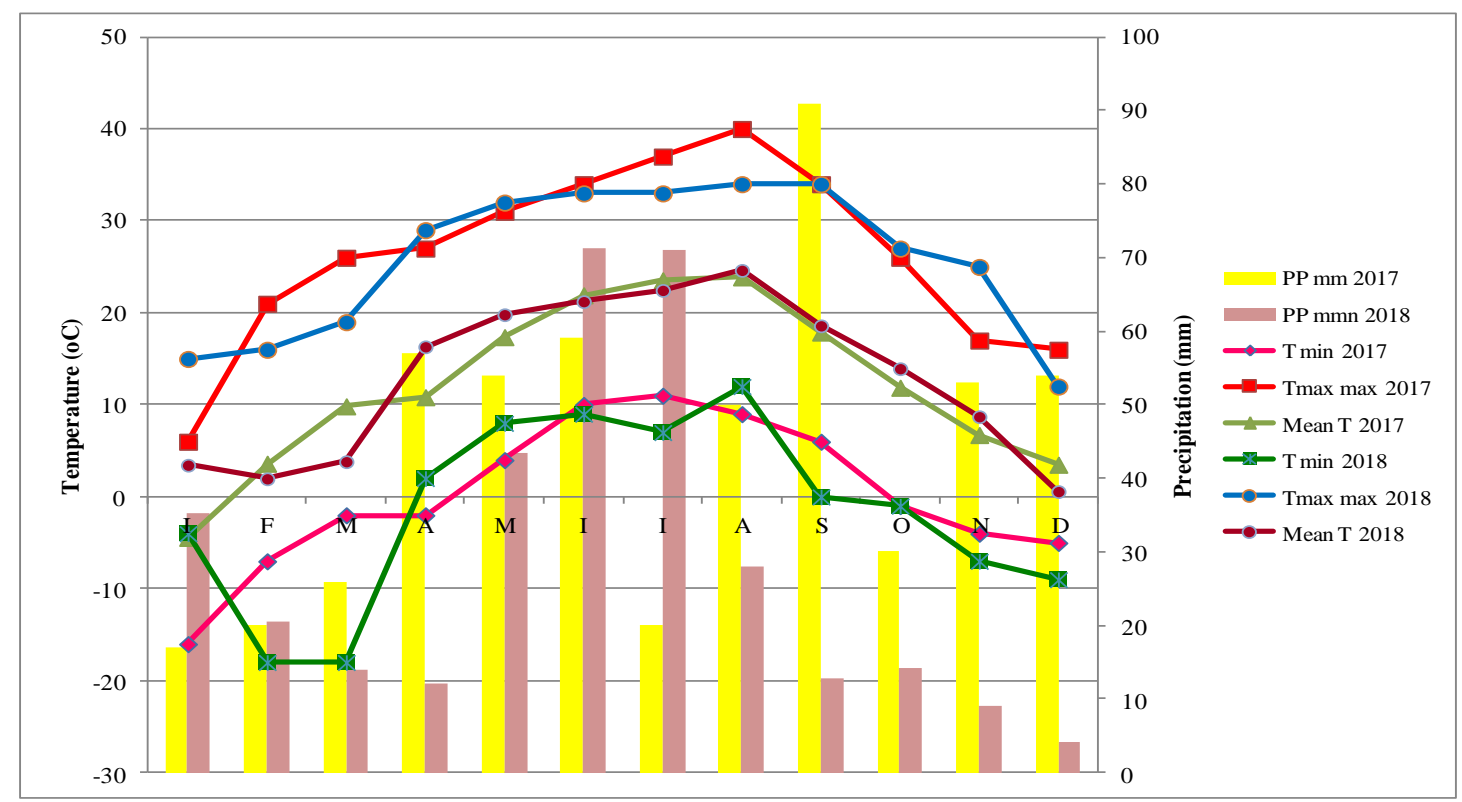

Figure 1. Temperature and precipitations during growing seasons (2017-2018)

http://www.natsci.upit.ro

*Corresponding author, E-mail address: madosae@yahoo.com 


\section{Current Trends in Natural Sciences}

Vol. 10, Issue 19, pp. 307-312, 2021

https://doi.org/10.47068/ctns.2021.v10i19.039

Current Trends in Natural Sciences (on-line)

ISSN: 2284-953X

Current Trends in Natural Sciences (CD-Rom)

ISSN: 2284-9521

ISSN-L: 2284-9521

ISSN-L: 2284-9521

The morphological parameters involved in the research were: the number of bunches / vine, the bunch weight, the number of berries / bunch and the yield of bunches on vine.

Data were statistically analysed. The significance of differences between the varieties was noted with symbols $(*, 0)$ (Ciulca, 2006).

\section{RESULTS AND DISCUSSIONS}

From the data presented in (table 1) it could observe that conditions of years had influence on number of bunches/vine to genotypes studied. The number of bunches/vine, registered value between ( 25.21 bunches /vine) in 2018 year and (23.87 bunches /vine) in conditions of the year 2017.

Table 1. The effect of the climatic conditions during research on the bunch number /vine

\begin{tabular}{|l|c|c|c|c|c|}
\hline Growing season & \multicolumn{2}{|c|}{ Average (g) } & $\begin{array}{l}\text { Relative } \\
\text { value\% }\end{array}$ & Difference & \multicolumn{1}{c|}{$\begin{array}{c}\text { Statistical } \\
\text { significance }\end{array}$} \\
\hline 2018- 2017 & 25.213 & 23.873 & 105.617 & 1.341 & - \\
\hline & & & LSD 5\% & LSD 1\% & LSD 0.1\% \\
\hline & & & 8.587 & 13.003 & 20.888 \\
\hline
\end{tabular}

Merlot variety recorded the highest number of bunches /vine (30.242) and Burgund variety recorded the lowest values of this character (17.767) (Table 2). Merlot and Cabernet sauvignon registered a significant differences compared with Burgund variety.

Table 2. The effect of grapevine varieties on the bunch number/vine

\begin{tabular}{|l|r|r|r|r|l|}
\hline \multicolumn{1}{|c|}{ Varieties } & \multicolumn{2}{c|}{$\begin{array}{c}\text { Average (number of } \\
\text { bunch/vine) }\end{array}$} & $\begin{array}{c}\text { Relative } \\
\text { value\% }\end{array}$ & Difference & $\begin{array}{c}\text { Statistical } \\
\text { significance }\end{array}$ \\
\hline Burgund -Pinot Noir & 17.767 & 20.280 & 87.607 & -2.513 & \\
\hline Merlot - Pinot Noir & 30.242 & 20.280 & 149.121 & 9.962 & $* *$ \\
\hline Cabernet Sauvignon - Pinot Noir & 29.883 & 20.280 & 147.354 & 9.603 & $* *$ \\
\hline Merlot - Burgund & 30.242 & 17.767 & 170.216 & 12.475 & $* * *$ \\
\hline Cabernet Sauvignon - Burgund & 29.883 & 17.767 & 168.199 & 12.117 & $* * *$ \\
\hline Cabernet Sauvignon - Merlot & 29.883 & 30.242 & 98.815 & -0.358 & \\
\hline & & LSD 5\% & LSD 1\% & LSD 0.1\% & \\
\hline & & 5.762 & 7.936 & 10.925 & \\
\hline
\end{tabular}

In (table 3) are summarized the results regarding the effect of climatic conditions during research on the bunch weight for the red grape varieties analysed. The bunch weight recorded values between 88.43 (g) in 2017 and $119.77 \mathrm{~g}$ in 2018. Results confirm that the bunch weight was lower during 2017 growing season.

Table 3. The effect of climate during growing seasons on the bunch weight

\begin{tabular}{|c|c|c|c|c|c|}
\hline Growing season & \multicolumn{2}{|c|}{ Average (g) } & $\begin{array}{c}\text { Relative } \\
\text { value\% }\end{array}$ & Difference & $\begin{array}{c}\text { Statistical } \\
\text { significance }\end{array}$ \\
\hline 2018- 2017 & 119.771 & 88.438 & 135.429 & 31.333 & - \\
\hline & & LSD 5\% & LSD 1\% & LSD 0.1\% & \\
\hline & & 38.192 & 57.834 & 92.909 & \\
\hline
\end{tabular}

http://www.natsci.upit.ro

*Corresponding author, E-mail address: madosae@yahoo.com 


\section{Current Trends in Natural Sciences}

Vol. 10, Issue 19, pp. 307-312, 2021

https://doi.org/10.47068/ctns.2021.v10i19.039

Current Trends in Natural Sciences (on-line)

In the vineyard the average weight of grapes is a very important character, which constitutes both an element of quality and an element of productivity (Tardea et al., 1995; Sestras, 2004).

Different bunch weight showed all varieties analysed; Burgund recorded the highest bunch average weight $(119.57 \mathrm{~g})$ followed by Merlot $(115.30 \mathrm{~g})$ while Pinot Noir recorded the lowest value (87.18 g) (table 4).

Table 4. The effect of grapevine varieties on the bunch weight

\begin{tabular}{|l|r|r|r|r|r|}
\hline \multicolumn{1}{|c|}{ Varieties } & \multicolumn{2}{|c|}{$\begin{array}{c}\text { Average of bunch } \\
\text { weight (g) }\end{array}$} & $\begin{array}{l}\text { Relative } \\
\text { value\% }\end{array}$ & Difference & $\begin{array}{c}\text { Statistical } \\
\text { significance }\end{array}$ \\
\hline Burgund -Pinot Noir & 119.578 & 87.183 & 137.157 & 32.395 & $*$ \\
\hline Merlot - Pinot Noir & 115.370 & 87.183 & 132.330 & 28.187 & $*$ \\
\hline Cabernet Sauvignon - Pinot Noir & 94.287 & 87.183 & 108.148 & 7.103 & \\
\hline Merlot - Burgund & 115.370 & 119.578 & 96.481 & -4.208 & \\
\hline Cabernet Sauvignon - Burgund & 94.287 & 119.578 & 78.849 & -25.292 & \\
\hline Cabernet Sauvignon - Merlot & 94.287 & 115.370 & 81.725 & -21.083 & \\
\hline & & LSD 5\% & LSD 1\% & LSD 0.1\% & \\
\hline & & 26.725 & 36.810 & 50.676 & \\
\hline
\end{tabular}

The climatic conditions in 2017 were less favourable for the berries number/bunch in red grape varieties (Table 5).

Table 5. The effects of climate conditions during growing seasons on the number of berries /bunch

\begin{tabular}{|c|c|c|c|c|c|}
\hline \multirow{2}{*}{ Periods } & \multicolumn{2}{|c|}{ Average (g) } & $\begin{array}{c}\text { Relative } \\
\text { value\% }\end{array}$ & Difference & $\begin{array}{c}\text { Statistical } \\
\text { significance }\end{array}$ \\
\hline 2018-2017 & 102.988 & 78.531 & 131.143 & 24.457 & \\
\hline & & & LDS 5\% & LDS 1\% & LDS 0.1\% \\
\hline & & & 32.816 & 49.692 & 79.829 \\
\hline
\end{tabular}

A very important role during the berry maturation, ripening, or development of physical as well as chemical characteristics of the berry quality such as: colour, size, aroma, berry growth and development, accumulation of anthocyanin, play climate. (Jackson, 1993).

A different number of berries per bunch showed all the varieties. The number of berries/bunch was smaller, on average 82.36 berries/bunch in the Pinot Noir variety and the maximum value of 111.73 berries/bunch on average in the Merlot variety. The number of berries per bunch is influenced by climate conditions during the flowering and/or fruit set (Iland et al., 2013, Velicevici et.al., 2020). Regarding the influence of the climatic conditions during research growing seasons, on the grape yield/vine, it is found that the growing season conditions from 2018 had a very significant positive influence on the grape yield / vine in all analysed varieties. The higher level of rainfall in $2018 \mathrm{had}$ a positive influence on the bunch weight/ vine in the harvest time. 


\section{Current Trends in Natural Sciences}

Vol. 10, Issue 19, pp. 307-312, 2021

https://doi.org/10.47068/ctns.2021.v10i19.039

Current Trends in Natural Sciences (on-line)

Table 6. The effect of grapevine varieties on the number of berries /bunches

\begin{tabular}{|l|r|r|r|r|l|}
\hline \multicolumn{1}{|c|}{ Variants } & \multicolumn{2}{c|}{$\begin{array}{c}\text { Average (number of } \\
\text { berries /bunches) }\end{array}$} & $\begin{array}{l}\text { Relative } \\
\text { value\% }\end{array}$ & Difference & $\begin{array}{c}\text { Statistical } \\
\text { significance }\end{array}$ \\
\hline Burgund -Pinot Noir & 90.318 & 82.367 & 109.653 & 7.951 & \\
\hline Merlot - Pinot Noir & 111.735 & 82.367 & 135.656 & 29.368 & $*$ \\
\hline Cabernet Sauvignon - Pinot Noir & 78.618 & 82.367 & 95.448 & -3.749 & \\
\hline Merlot - Burgund & 111.735 & 90.318 & 123.714 & 21.418 & \\
\hline Cabernet Sauvignon - Burgund & 78.618 & 90.318 & 87.046 & -11.700 & \\
\hline Cabernet Sauvignon - Merlot & 78.618 & 111.735 & 70.361 & -33.118 & oo \\
\hline & & & DL 5\% & DL 1\% & DL 0.1\% \\
\hline & & & 23.569 & 32.463 & 44.693 \\
\hline
\end{tabular}

Table 7. The effect of growing season on the grape yield/vine

\begin{tabular}{|c|c|c|c|c|c|}
\hline $\begin{array}{c}\text { Growing } \\
\text { season }\end{array}$ & \multicolumn{2}{|c|}{$\begin{array}{c}\text { Average (g) } \\
\text { Anative } \\
\text { value\% }\end{array}$} & Difference & $\begin{array}{c}\text { Statistical } \\
\text { significance }\end{array}$ \\
\hline $2018-2017$ & 3111.529 & 2096.287 & 148.431 & 1015.243 & $* * *$ \\
\hline & & & LDS 5\% & LDS 1\% & LDS 0.1\% \\
\hline & & & 59.134 & 89.546 & 143.853 \\
\hline
\end{tabular}

For red wine varieties the average values of yield / vine (Table 8) showed amplitude of $1463.87 \mathrm{~g}$, with limits from $2137.19 \mathrm{~g}$. in Burgund to $3600.87 \mathrm{~g}$ in Merlot.

The Merlot variety achieved a significantly higher production than the other varieties during both growing seasons. Cabernet Sauvignon variety was also recorded a higher value of this parameter.

Table 8. The effect of grapevine varieties on the grape yield/vine

\begin{tabular}{|c|c|c|c|c|c|}
\hline Variants & \multicolumn{2}{|c|}{ Average(g) } & $\begin{array}{l}\begin{array}{l}\text { Relative } \\
\text { value\% }\end{array} \\
\end{array}$ & Difference & $\begin{array}{c}\text { Statistical } \\
\text { significance }\end{array}$ \\
\hline Burgund -Pinot Noir & 2137.192 & 1938.500 & 110.250 & 198.692 & $* * *$ \\
\hline Merlot - Pinot Noir & 3600.873 & 1938.500 & 185.756 & 1662.373 & **** \\
\hline Cabernet Sauvignon - Pinot Noir & 2739.067 & 1938.500 & 141.298 & 800.567 & $* * *$ \\
\hline Merlot - Burgund & 3600.873 & 2137.192 & 168.486 & 1463.682 & $* * *$ \\
\hline Cabernet Sauvignon - Burgund & 2739.067 & 2137.192 & 128.162 & 601.875 & $* * *$ \\
\hline \multirow[t]{3}{*}{ Cabernet Sauvignon - Merlot } & 2739.067 & 3600.873 & 76.067 & -861.807 & Ooo \\
\hline & & & DL 5\% & DL $1 \%$ & DL $0.1 \%$ \\
\hline & & & 51.438 & 70.848 & 97.538 \\
\hline
\end{tabular}

Lower values of yield/ vine were recorded in the Pinot Noir variety, suggesting a special adaptation to less favourable environmental conditions.

\section{CONCLUSIONS}

The obtained results show that there are differences from one vegetation season to another for the analysed parameters. Merlot variety registered the highest number of bunches/vine (30.24), while 
Burgund variety recorded the lowest values (17.76). Burgund variety recorded the highest bunch average weight (119.57 g) followed by Merlot (115.30 g) while Pinot Noir recorded the lowest value $(87.18 \mathrm{~g})$. The Merlot variety achieved a significantly higher production than the other varieties during both growing seasons $(3600.87 \mathrm{~g})$.

The conditions of 2018 growing season had a very significant positive influence on the grape yield/ vine.

\section{REFERENCES}

Ciulca S., (2006). Metodologii de experimentare in agricultura si biologie [Experimental Methodologies in Agriculture and Biology]. Agroprint Publishing House, Timişoara

Dobrei A, Dobrei A.G., Sala F, Nistor E., Mălăescu M., Dragunescu A., Cristea T., (2014) Research concerning the influence of soil maintenance on financial performance of vineyards, Journal of Horticulture, Forestry and Biotechnology 18(1): 156- 164

Gerendás J., Führs H. (2013). The significance of magnesium for crop quality. Plant and Soil, 368: 101-128

Iland P., et al. (2011). The grapevine: from the science to the practice of growing vines for wine. Patrick Iland Wine Promotions Pty Ltd. Adelaide, Australia.

Jackson D. I., Lombard P. B., (1993). Environmental and management practices affecting grape composition and wine quality - A review, American Journal of Enology and Viticulture 44: 409-430.

Jordão A.M., Vilela Alice, Cosme Fernanda, (2015).Review: From sugar of grape to alcohol of wine: sensorial impact of alcohol in wine, Beverages, 1(4), 292-310; doi:10.3390/beverages 1040292

Jukes Matthew, (2015). Cartea vinurilor - Schimbă-ți felul în care gândești despre vin Wine Book [ Change the way you think about wine], Edition a II-a, Ed. Paralela 45, Pitești

Kuhn Nathalie, Guan Le, Wu Dai Zhan, Wu Ben-Hong, Lauvergeat Virginie, Gomès E., Li Shao-Hua, Godoy Francisca , Arce-Johnson P., Delrot S., (2014) Berry ripening: recently heard through the grapevine, Journal of Experimental Botany, 65 (16): 4543-4559

Madosa E., (2004). Ameliorarea plantelor horticole [Plant breeding og horticultural plants], Ed. Eurobit Timisoara

Nistor Eleonora, Dobrei Alina Georgeta, Dobrei A., Camen D., Velicevici Giancarla, Prundeanu H., Baiduc M. (2017). Crop estimation and variability of yield components in Cabernet Sauvignon, Merlot, Pinot Noir and Burgundy varieties JOURNAL of Horticulture, Forestry and Biotechnology Volume 21(4), 73- 76,

Old Marnie, (2016). Vinul cum îl înțelegem, cum îl bem [Wine as we understand it, as we drink it ]- Ghid de degustare [Tasting guide], Ed. Litera, București

Sestraş R., (2004). Ameliorarea speciilor horticole [Improvement of Horticultural Varieties].AcademicPres Publishing House, ClujNapoca.

Stoica Valeriu, (2016). Prestigiul și modestia - prefață la cartea Expert în vin în 24 de ore, [Prestige and modesty preface to the book Expert in wine in 24 hours, de Jancis Robinson], Editura Baroque Books\&Arts, Bucureși, colecția "In Vino Veritas"

Ţardea C., Dejeu L., (1995). Viticultura, [Viticulture] Ed. Didactică şi Pedagogică, Bucureşti 104;

Zörb Ch., Senbayram M., Peiter E. (2014). Potassium in agriculture - Status and perspectives. Journal of Plant Physiology, 171: 656-669

Velicevici Giancarla, Madoşă E., Ciulca Adriana, Ciulca S., Camen D., Mihaela Mălăescu, Renato Coradini (2020). Study regarding variability of yield components in some grapevine varieties for white wines, Current Trends in Natural Sciences, Vol. 9, Issue 17, pp. 97-103. 